\title{
Electroless Plating of Organic Pigments onto a Metal Fine Particle Using Surfactants Containing an Azobenzene Group
}

\author{
Tetsuo SAJI*, Akira NAKANE* and Shunlin LIU* \\ アソ゚ベンゼン修飾界面活性剂を用いた金属微粒子への顔料の無電解めっき
}

佐治 哲夫*, 中根 章*, 劉 順林*

Key Words : Fine Particle, Electroless Plating, Copper Phthalocyanine, Azobenzene, Surfactant

\section{Introduction}

The study of fine particles is of great interest for materials of electronic devices, catalysts, gas sensors, etc ${ }^{1)}$. Their surface modification is important to improve their functions ${ }^{2)}$. Recently, we demonstrated that following surfactant containing an azobenzene group 1 loses its amphiphilic function upon reduction and this phenomenon was applied to electroless plating of organic thin films on base metals by simple immersion ${ }^{3), 4)}$ :

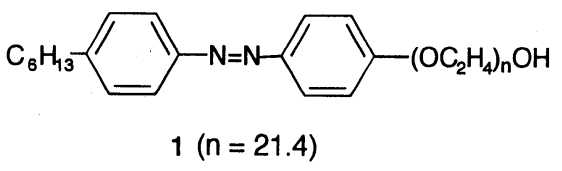

Furthermore, we reported contact plating of organic thin films on noble metal and ITO substrates using the same surfactant ${ }^{5)}$. In this paper, we report the electroless plating of organic pigments on fine particles of copper and nickel. This method enables us to fabricate fine particles only by immersion into the pigment dispersion.

\section{Experimental}

The preparation of surfactant 1 has been described in our previous paper ${ }^{3)}$. As the film forming material, $\beta$-type copper phthalocyanine (particle size 0.1-0.2 $\mu \mathrm{m}$, Dainichiseika Color \& Chemicals, 2) and 4,4'-diamino-1,1'-bianthracene$9,9^{\prime}, 10,10^{\prime}$-tetrone $(0.02-0.04 \mu \mathrm{m}$, Ciba-Geigy, 3) were used. A dispersion containing $1 \mathrm{mM}(1 \mathrm{M}=$ $1 \mathrm{~mol} \mathrm{dm}^{-3}$ ) 1, $0.1 \mathrm{M} \mathrm{HCl}$ and 2 (or 3) was prepared by sonicating the mixture for $10 \mathrm{~min}$ twice (Tomy Seiko Ultrasonic Disruptor Model UR200P). Fine particles of metallic nickel (The Nilaco Corp.) and copper (Kanto Chem. Co. Inc.)

\footnotetext{
* Dept. of Chemical Eng., Tokyo Inst. of Tech. (Ohokayama, Meguro-ku, Tokyo 152, Japan)

東京工業大学 工学部
}

were used. Their average particle sizes were 3.0 and $0.25 \mu \mathrm{m}$, respctively. Electroless plating of the pigment was performed by immersing these particles in the dispersion. The plating was stopped by dilution of the dispersion with distilled water. The nickel particles plated with the pigment were removed with a magnet. The amount of the pigment on the metal particles was determined by the absorption spectrum of an aqueous dispersion prepared by washing these particles with a $5 \mathrm{mM}$ Brij aqueous solution.

\section{Results and Discussion}

Bluish particles were obtained by immersion of the nickel and copper particles into the dispersion

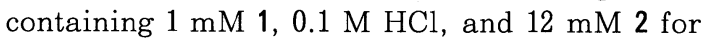
$30 \mathrm{~min}$. Reddish particles were also obtained by immersion of the nickel particles into the dispersion containing $1 \mathrm{mM} 1,0.1 \mathrm{M} \mathrm{HCl}$, and $10 \mathrm{mM}$ 3 for $30 \mathrm{~min}$. Fig. 1 shows SEM photographs of the nickel particles before and after plating of 2 . The size of the particle increased by more than 3 times. The thickness of the pigment layer is estimated to be more than $3 \mu \mathrm{m}$ from this change in particle size. This pigment layer is composed of $0.1-0.2 \mu \mathrm{m}$ particles, which are the same as those used for the dispersion. The absorption spectrum of an aqueous dispersion prepared by washing these particles with a $5 \mathrm{mM}$ Brij 35 aqueous solution consisted of broad peaks and was very similar to that for a $5 \mathrm{mM}$ Brij 35 aqueous dispersion of $2^{6)}$. These results indicate that these films are mainly made of 2 . Fig. 2 shows a plot of the size of the nickel particle versus immersion time. After the substrate was covered with the 2 film, this film continued to grow. The film thickness increases with immersion time and up to more than $4 \mu \mathrm{m}$. This is ascribable to penetration of the surfactant into the film, due to the existence of small spaces in the film. The amount of $\mathbf{2}$ on the nickel particles increased with 


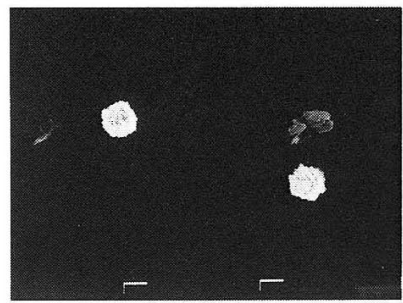

(a)

$$
10 \mu \mathrm{m}
$$

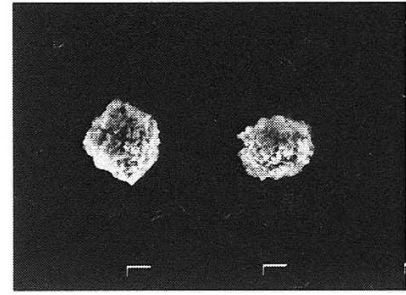

(b)

$10 \mu \mathrm{m}$

Fig. 1 SEM photographs of the nickel particles (a) before and (b) after plating of 2 for $30 \mathrm{~min}$.

immersion time.

Such electroless plating of organic pigments onto fine metallic particles may be explained by the same mechanism as that for base metal plates $^{3)}: 1$ is reduced to the aniline derivative at the surface of the base metal particle, which loses its function as a surfactant due to enhancement of the tail group's hydrophilicity, since the redox potentials of these metals are more negative than the reduction potential of 1 (approximately -0.1 $\left.\mathrm{V}^{3)}\right)$.

\section{Conclusion}

The present experiments show that the electro-

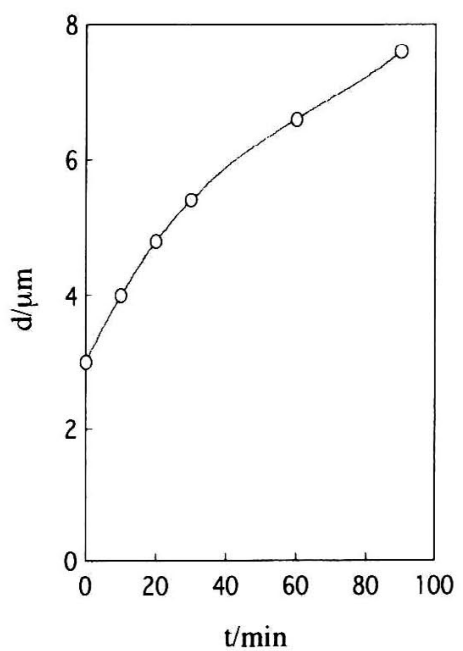

Fig. 2 The diameter (d) of the nickel particles versus immersion time $(t)$.

less plating technique using 1 serves as a tool for the surface modification of fine base metal particles with organic compounds.

(Received March 14, 1996 ; Accepted May 15, 1996)

\section{References}

1) M. Koishi ; Biryushi Sekkei, Eds. by M. Koishi, Chap. 1 (Kogyo Chosakai Pub. Co., Ltd., Tokyo 1987)

2) M. Koishi ; Hyomen, 25, 1 (1987)

3) T. Saji, K. Ebata, K. Sugawara, S. Liu, and K. Kobayashi ; J. Am. Chem. Soc., 116, 6053 (1994)

4) N. K. Shrestha and T. Saji ; Hyomen Gijutsu, 46, 1066 (1995)

5) T. Saji, Y. Igusa, K. Kobayshi, and S. Liu ; Chem. Lett., 1995, 401

6) T. Saji and Y. Ishii ; J. Electrochem. Soc., 136, 2953 (1989) 